\title{
Impact of acute undernutrition on growth, ileal morphology and nutrient transport in a murine model
}

\author{
I.C. Sampaio ${ }^{1}$, P.H.Q.S. Medeiros ${ }^{1}$, F.A.P. Rodrigues ${ }^{1}$, P.A. Cavalcante ${ }^{1}$, S.A. Ribeiro ${ }^{1}$, \\ J.S. Oliveira ${ }^{1}$, M.M.G. Prata ${ }^{1}$, D.V.S. Costa ${ }^{1}$, S.G.C. Fonseca ${ }^{2}$, M.M. Guedes ${ }^{1}$, A.M. Soares ${ }^{1}$, \\ G.A.C. Brito ${ }^{1}$, A. Havt ${ }^{1}$, S.R. Moore ${ }^{3 *}$ and A.A.M. Lima ${ }^{1}$ \\ ${ }^{1}$ Departamento de Fisiologia e Farmacologia, Faculdade de Medicina, Instituto de Biomedicina, \\ Universidade Federal do Ceará, Fortaleza, CE, Brasil \\ ${ }^{2}$ Departamento de Farmácia, Universidade Federal do Ceará, Fortaleza, CE, Brasil \\ ${ }^{3}$ Division of Gastroenterology, Hepatology, and Nutrition, Cincinnati Children's Hospital Medical Center, Cincinnati, OH, USA
}

\begin{abstract}
Undernutrition represents a major public health challenge for middle- and low-income countries. This study aimed to evaluate whether a multideficient Northeast Brazil regional basic diet (RBD) induces acute morphological and functional changes in the ileum of mice. Swiss mice ( $\sim 25 \mathrm{~g}$ ) were allocated into two groups: i) control mice were fed a standard diet and II) undernourished mice were fed the RBD. After 7 days, mice were killed and the ileum collected for evaluation of electrophysiological parameters (Ussing chambers), transcription (RT-qPCR) and protein expression (western blotting) of intestinal transporters and tight junctions. Body weight gain was significantly decreased in the undernourished group, which also showed decreased crypt depth but no alterations in villus height. Electrophysiology measurements showed a reduced basal short circuit current $\left(I_{\mathrm{sc}}\right)$ in the undernourished group, with no differences in transepithelial resistance. Specific substrate-evoked $I_{\text {sc }}$ related to affinity and efficacy (glutamine and alanyl-glutamine) were not different between groups, except for the maximum $I_{\text {sc }}$ (efficacy) induced by glucose. Transcription of Sglt1 and Pept1 was significantly higher in the undernourished group, while SN-2 transcription was decreased. No changes were found in transcription of CAT-1 and CFTR, while claudin-2 and occludin transcriptions were significantly increased in the undernourished group. Despite mRNA changes, SGLT-1, PEPT-1, claudin-2 and occludin protein expression showed no difference between groups. These results demonstrate early effects of the RBD on mice, which include reduced body weight and crypt depth in the absence of significant alterations to villus morphology, intestinal transporters and tight junction expression.
\end{abstract}

Key words: Undernutrition; Ion transport; Intestinal absorption

\section{Introduction}

Undernutrition is defined as a physiological outcome of illness and/or hunger, which subclassifies as wasting (an acute state), stunting (a chronic state), underweight (mixed acute and/or chronic states) and micronutrient deficiencies. This condition has a great impact on global public health, especially in middle- and low-income countries $(1,2)$, and is the cause of 3.1 million child deaths annually. Further, it is estimated that $25.7 \%$ (about 165 million) of children younger than 5 years suffer from stunting, while $10.9 \%$ ( $\sim 70$ million) and $15.7 \%$ ( $\sim 100$ million) suffer from wasting and underweight, respectively (3). Further evaluation of childhood undernutrition-associated consequences has worrisome social implications, such as impaired school performance (4), increased economic costs (5), impaired immunity (6) and a significantly higher number of deaths due to infectious diseases (7).

The regional basic diet (RBD) is an experimental rodent diet based on the nutritional intake of the northeastern Brazilian population and is characterized by a deficit of protein, fat and minerals, which trigger some clinical symptoms of kwashiorkor and stunting, commonly reported in this population $(8,9)$. Some studies have used the RBD in mouse models of undernutrition (10-12). Chronically, the RBD promotes deleterious effects in the small intestine with altered villous height and crypt depth, reduced transmucosal resistance, increased permeability and enhanced epithelial apoptosis (12).

Several studies seek to understand the pathophysiology of undernutrition by characterizing alterations of transcellular

Correspondence: A.A.M. Lima: <alima@ufc.br>

*The current address of S.R. Moore is: Division of Gastroenterology and Nutrition, Department of Pediatrics, University of Virginia, Charlottesville, VA, USA. 
and paracellular transports (12-19). Transmembrane proteins, such as sodium-glucose linked transporter 1 (SGLT-1), peptide transporter 1 (PEPT-1) and cationic amino acid transport-1 (CAT-1), are modulated by undernourished states $(14-16,19)$. Conversely, the paracellular transport mediating tight junctions, such as claudins, occludins and zonula occludens, have been described as fundamental for absorption of electrolytes and water in the small intestine, and are modulated by undernutrition as well $(12,13,17-19)$.

Generally, the clinical management of undernutrition requires early detection of pathophysiological changes. As the majority of studies have shown only the long-term effects of RBD, we examined if the RBD induces acute morphological and functional changes in the ileum in a short period of time, evaluating modifications of electrophysiological parameters and transcription and expression of intestinal transporters and tight junction proteins.

\section{Material and Methods}

\section{Animals and experimental design}

Male Swiss mice (total of 28 ) weighing $\sim 25 \mathrm{~g}$ were obtained from the Departamento de Fisiologia e Farmacologia, Universidade Federal of Ceará, and maintained under controlled temperature $\left(21 \pm 2^{\circ} \mathrm{C}\right)$ and humidity $(60 \pm 5 \%)$, and a 12:12 h light:dark cycle. Mice had access to a standard commercial diet and water ad libitum. The animal protocols were performed according to the norms of the National Council for Control of Animal Experimentation (CONCEA) and were approved by the Ethics Committee of Animal Research of the Universidade Federal do Ceará, Fortaleza, CE, Brazil (protocol \#62/11).

Mice were divided randomly into two groups. The control group was fed a standard diet (Biotec ${ }^{\circledR}$, Brazil) while the experimental undernourished group was fed the RBD diet. The RBD diet was developed at the Laboratório de Farmacotécnica, Universidade Federal do Ceará, as previously described $(8,9)$. The composition of these diets is shown in Figure 1.

During the experimental period, animals were maintained in metabolic cages. Weight, and food and water intake were measured daily. After seven days of RBD feeding, electrophysiological parameters, intestinal morphometry, gene transcription and expression of intestinal transporters and tight junction proteins were evaluated from ileal segments. After anesthetizing animals with $10 \mathrm{mg} / \mathrm{kg}$ xylazin and $90 \mathrm{mg} / \mathrm{kg}$ ketamine, intestinal segments were collected and major blood vessels ligated to induce exsanguination.

\section{Ussing chambers system}

We evaluated the transport of glucose, glutamine and alanyl-glutamine by Ussing chambers as previously described (12). Eight-centimeter ileal segments were collected, quickly dissected from serous membrane, opened along the mesenteric attachment remnant and cut

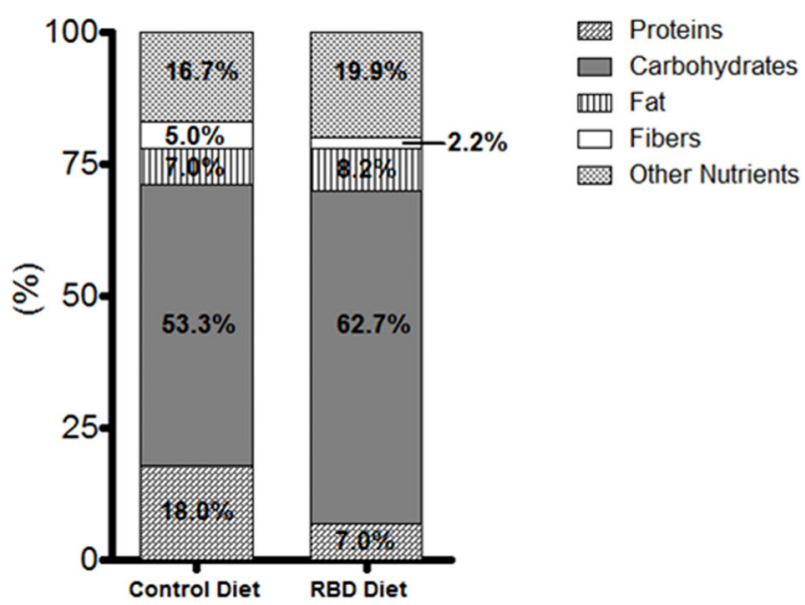

Figure 1. Composition of the regional basic diet (RBD) and control diet reported as percent of total calories. The RBD diet contains a higher amount of carbohydrates and lower quantity of protein than the control diet.

into $1.5 \mathrm{~cm}$ pieces inside Petri dishes containing Krebs solution. The tissue was immediately mounted in Ussing chambers with the mucosal side faced up on the hemichamber (WPI, USA). For each experiment, the average tissue loss was less than $20 \%$. Each assay was performed with 2 mice; one undernourished and one control, from which four ileal segments were collected. The tissue was perfused with Krebs solution (10 $\mathrm{mM}$ glucose in serosal and $10 \mathrm{mM}$ mannitol in mucosa) containing $115 \mathrm{mM} \mathrm{NaCl}$, $25 \mathrm{mM} \mathrm{NaHCO}_{3}, 2.4 \mathrm{mM} \mathrm{K}_{2} \mathrm{HPO}_{4}, 1.2 \mathrm{mM} \mathrm{CaCl}_{2}, 1.2 \mathrm{mM}$ $\mathrm{MgCl}_{2}$, and $0.4 \mathrm{mM} \mathrm{KH}_{2} \mathrm{PO}_{4}, \mathrm{pH} 7.4$. This buffer was continuously gassed with $95 \% \mathrm{O}_{2} / 5 \% \mathrm{CO}_{2}$, and temperature was kept at $37^{\circ} \mathrm{C}$ using a circulating water pump controlled by a thermostat.

After a 30-min period for reaching a state of equilibrium, short circuit current $\left(\mathrm{I}_{\mathrm{sc}}\right)$ was measured before and after cumulative addition of glucose, glutamine or alanylglutamine at concentrations of 1, 2, 7, 20, 70, and $200 \mathrm{mM}$ applied to the mucosal side. The osmolarity of these solutions was adjusted to 300 milliosmoles by adding Ringer solution. To calculate resistance, a constant $50 \mu \mathrm{A}$ current was applied. This value and the elicited spontaneous potential difference (PD) were inserted as input variables into Ohm's law, and the result was multiplied by 20 for unit normalization, as follows: $R$ (resistance) $=\mathrm{PD} / \mathrm{I}_{\text {sc }}$. The electrical viability of intestinal samples was verified after each experiment by evaluating electrical response to the addition of theophylline $(5 \mathrm{mM})$ to the serosal side of the tissue. This addition inhibits phosphodiesterase enzyme, leading to elevated AMPc and consequent increased chloride secretion, demonstrated by the increased $\mathrm{I}_{\mathrm{sc}}(20)$.

\section{Intestinal morphology analyses}

lleal segments were fixed with paraformaldehyde, dehydrated with ascending $70,80,90$, and $100 \%$ ethanol 
Table 1. Description of genes, primers sequences, accession numbers (NCBI) and qRT-PCR conditions.

\begin{tabular}{|c|c|c|}
\hline $\begin{array}{l}\text { Genes/Primers } \\
\text { sequences }\left(5^{\prime}-3^{\prime}\right)\end{array}$ & $\begin{array}{l}\text { GenBank (NCBI) } \\
\text { accession number }\end{array}$ & $\begin{array}{l}\text { Annealing temperature } \\
\text { (40 cycles })^{*}\end{array}$ \\
\hline \multicolumn{3}{|l|}{ ZO-1 } \\
\hline GACCATCGCCTACGGTTTGA & \multirow[t]{2}{*}{ NM_001163574.1 } & \multirow[t]{2}{*}{$20^{\prime \prime}, 60^{\circ} \mathrm{C}$} \\
\hline AGGTCTCGGGGATGCTGATT & & \\
\hline \multicolumn{3}{|l|}{ Claudin-1 } \\
\hline TCTACGAGGGACTGTGGATG & \multirow[t]{2}{*}{ NM_016674.4 } & \multirow[t]{2}{*}{$20^{\prime \prime}, 58^{\circ} \mathrm{C}$} \\
\hline TCAGATTCAGCAAGGAGTCG & & \\
\hline Claudin -2 & & \\
\hline CCCACCACCACCAGCTTAAT & \multirow[t]{2}{*}{ NM_016675.4 } & \multirow[t]{2}{*}{$20^{\prime \prime}, 60^{\circ} \mathrm{C}$} \\
\hline GAAATGGCTTCCAGGTCAGC & & \\
\hline \multicolumn{3}{|l|}{ Occludin } \\
\hline AAGAGCAGCCAAAGGCTTCC & \multirow[t]{2}{*}{ NM_008756.2 } & \multirow[t]{2}{*}{$20^{\prime \prime}, 60^{\circ} \mathrm{C}$} \\
\hline CGTCGGGTTCACTCCCATTA & & \\
\hline \multicolumn{3}{|l|}{ SGLT-1 } \\
\hline CGGAAGAAGCGATCTGAGAA & \multirow[t]{2}{*}{ NM_019810.4 } & \multirow[t]{2}{*}{$20^{\prime \prime}, 58^{\circ} \mathrm{C}$} \\
\hline AATCAGCACGAGGATGAACA & & \\
\hline \multicolumn{3}{|l|}{ SN-2 } \\
\hline ATATCCTCGTCATCTGTGTGC & \multirow[t]{2}{*}{ NM_172479.2 } & \multirow[t]{2}{*}{$20^{\prime \prime}, 60^{\circ} \mathrm{C}$} \\
\hline CAGTAGGTACAATACGGAGGTAGA & & \\
\hline \multicolumn{3}{|l|}{ CAT-1 } \\
\hline CTTTGGATTCTCTGGTGTCCTGTC & \multirow[t]{2}{*}{ NM_007513.4 } & \multirow[t]{2}{*}{$20^{\prime \prime}, 58^{\circ} \mathrm{C}$} \\
\hline GTTCTTGACTTCTTCCCCTGTGG & & \\
\hline PEPT-1 & & \\
\hline AGGGGAGAACGGAATCAGGT & \multirow[t]{2}{*}{ NM_053079.2 } & \multirow[t]{2}{*}{$20^{\prime \prime}, 60^{\circ} \mathrm{C}$} \\
\hline CTTTTCGCCAGAAGGGAAGA & & \\
\hline \multicolumn{3}{|l|}{ CFTR } \\
\hline GGATGCTGAGGAAGCAACTC & \multirow[t]{2}{*}{ NM_021050.2 } & \multirow[t]{2}{*}{$20^{\prime \prime}, 58^{\circ} \mathrm{C}$} \\
\hline CCAGCCTGGAACTCTCTTTG & & \\
\hline \multicolumn{3}{|l|}{ Ppia } \\
\hline AATGCTGGACCAAACACAAA & \multirow[t]{2}{*}{ NM_008907.1 } & \multirow[t]{2}{*}{$20^{\prime \prime}, 58^{\circ} \mathrm{C}$} \\
\hline TTCCACAATGTTCATGCCTT & & \\
\hline
\end{tabular}

* Every cycle began with a denaturing step $\left(20 \mathrm{~s}\right.$ at $\left.95^{\circ} \mathrm{C}\right)$ and finished with an extension of $45 \mathrm{~s}$ to $1 \mathrm{~min}$ at $72^{\circ} \mathrm{C}$.

and processed in paraffin. The resulting blocks were sliced into 5- $\mu \mathrm{m}$-thick sections, stained with hematoxylin and eosin (H\&E), and observed under a light microscope $(\times 400)$. The area of the villi and crypt depth were measured as previously described (21) using Image $\mathrm{J}$ software version 1.6.0 (National Institutes of Health, USA).

\section{Evaluation of gene transcription of intestinal transporters and tight junctions}

Gene transcription of sodium-glucose linked transporter (SGLT-1), system N-transporter (SN-2), cationic amino acid transporter (CAT-1), peptide transporter 1 (PEPT-1), cystic fibrosis transmembrane conductance regulator (CFTR,) zonula occludens-1 (ZO-1), claudin-1, claudin-2, and occludin was determined by quantitative reverse transcription-polymerase chain reaction (qRT-PCR). Initially, total RNA was isolated from mucosal membrane of ileal segments using RNeasy mini Kit (Qiagen, Germany) according to the manufacturer's instructions. The cDNA was synthesized using iScript ${ }^{\mathrm{TM}}$ cDNA Synthesis Kit (Invitrogen, USA). The reference gene peptidylprolyl isomerase $A$ was used for this experiment (22). The primers design was based on mRNA sequences obtained from the National Center for Biotechnology Information (http://www.ncbi. nlm.nih.gov; accessed on February 4, 2014).

The qRT-PCR reactions were performed in a final volume of $25 \mu \mathrm{L}$ containing $12.5 \mu \mathrm{L}$ of $\mathrm{iQ}$ SYBR green supermix (Bio-Rad, USA), $200 \mathrm{nM}$ (each) primers, and $1 \mu \mathrm{L}$ of cDNA from sample. All primers and conditions for qRTPCR are shown in Table 1. To measure the specificity of the applied amplifications (i.e., to determine whether the formed products were specific for the tested genes), we performed a melting curve analysis in which the reaction temperature was increased $0.5^{\circ} \mathrm{C}$ every $15 \mathrm{~s}$, beginning at 
the annealing temperature of the tested set of primers and ending at $95^{\circ} \mathrm{C}$. Throughout the curve construction process, the changes in fluorescence were measured, and the data obtained, using CFX Manager software (version 3.0; Bio-Rad), were based on the values for the threshold cycle, i.e., where the observed fluorescence was 10-fold higher than the basal fluorescence for each reaction. Gene transcription was obtained by applying the mathematical $2^{-\Delta \Delta} \mathrm{CT}$ method (23).

\section{Immunoblot analysis}

In order to quantify SGLT-1, PEPT-1, claudin-2 and occludin proteins, mucosal membranes from ileal segments were homogenized in RIPA lysis buffer $(25 \mathrm{mM}$ Tris-HCL, pH 7.6; 150 mM NaCl; 5 mM EDTA; 1\% NP40; $1 \%$ triton $\mathrm{X}-100 ; 1 \%$ sodium deoxycholate; $0.1 \%$ SDS) and protease inhibitor ( $1 \mu \mathrm{L}$ inhibitor: $100 \mu \mathrm{L}$ RIPA). The homogenates were centrifuged $\left(17,949 \mathrm{~g}, 17 \mathrm{~min}, 4^{\circ} \mathrm{C}\right)$, and the supernatant was collected. Protein concentrations were determined through the bicinchoninic acid assay using PierceTM BCA protein assay kit (Thermo Scientific, USA). The protein $(20 \mu \mathrm{g})$ was prepared adding Laemmli sample buffer with $\beta$-mercaptoethanol and denatured at $95^{\circ} \mathrm{C}$ for $5 \mathrm{~min}$, except for PEPT-1, SGLT-1 and occludin. Then, proteins were separated in a SDS-polyacrylamide gel $(8 \%$ for occludin, SGLT-1 and PEPT- 1 analysis and $12.5 \%$ for claudin analysis) under a condition of 120 volts and transferred to polyvinylidene difluoride (PVDF) membranes by electrophoresis for $2 \mathrm{~h}$. PVDF membranes were blocked with $5 \%$ bovine serum albumin for $1 \mathrm{~h}$ and incubated overnight with primary rabbit antibody [anti- $\beta$ actin (1:1000), anti-SGLT-1 (1:500), anti-PEPT-1 (1:200), anti-claudin-2 (1:100), or anti-occludin (1:1000); Santa Cruz Biotechnology, USA]. Chemiluminescent detection using Clarity Western ECL Substrate (Bio-Rad) was performed after incubation of the membrane with secondary antibody (1:1000) for $1 \mathrm{~h}$. Finally, bands were captured using the ChemiDoc system (Bio-Rad). Densitometric quantification of bands was made using Image $\mathrm{J}$ software version 1.6.0 (National Institutes of Health).

\section{Statistical analysis}

Data are reported as means \pm SE. One- or two-way analysis of variance (ANOVA) followed by the Bonferroni's post hoc test were used for parametric data. Gene transcription data were evaluated by the Mann-Whitney test. Differences were considered to be statistically significant when $\mathrm{P}<0.05$. Analysis was performed using GraphPad Prism 5.0 (GraphPad Software, USA).

\section{Results}

\section{Impact of RBD diet for 7 days on body weight}

RBD feeding triggered a significant decrease in body weight gain when compared to the nourished group during the short period of 7 days $(P<0.001)$. This difference was
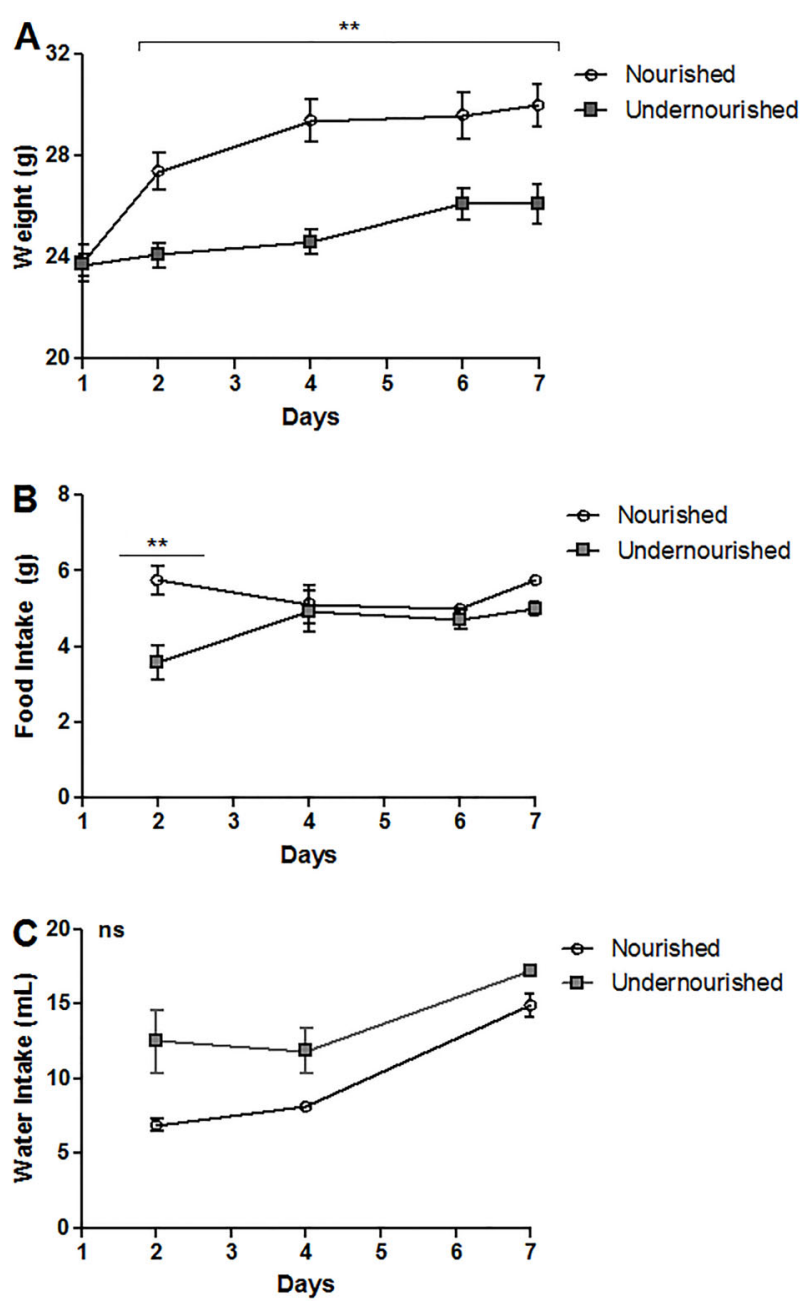

Figure 2. Weight curves from the regional basic diet (RBD) murine model of moderate acute undernutrition. The weight $(A)$, food $(B)$ and water $(C)$ intake are shown after a 7-day challenge with the RBD. ns: non-significant. Data are reported as means $\pm S E(n=4)$. ${ }^{* *} \mathrm{P}<0.001$ (ANOVA with the Bonferroni's multiple comparison test).

observable by the second day of intake, showing a reduction of $13.3 \%$ from the previous time point (nourished $30.0 \pm 0.8$ vs $26.10 \pm 0.7 \mathrm{~g}$ undernourished; Figure $2 \mathrm{~A}$ ). In addition, food intake was higher in the nourished group until day $2(P<0.01)$, and this difference was not observed subsequently (Figure 2B). Water intake did not differ statistically between the groups (Figure 2C).

\section{Impact of RBD diet for 7 days on intestinal morphology}

The intestinal morphometry of the ileum (Figure $3 \mathrm{~A}$ and $B$ ) in the 7-days RBD diet group did not change with respect to the area of the villi compared to nourished control group (Figure 3C). Morphometric analysis showed a significant decrease in the depth of the crypts in the 

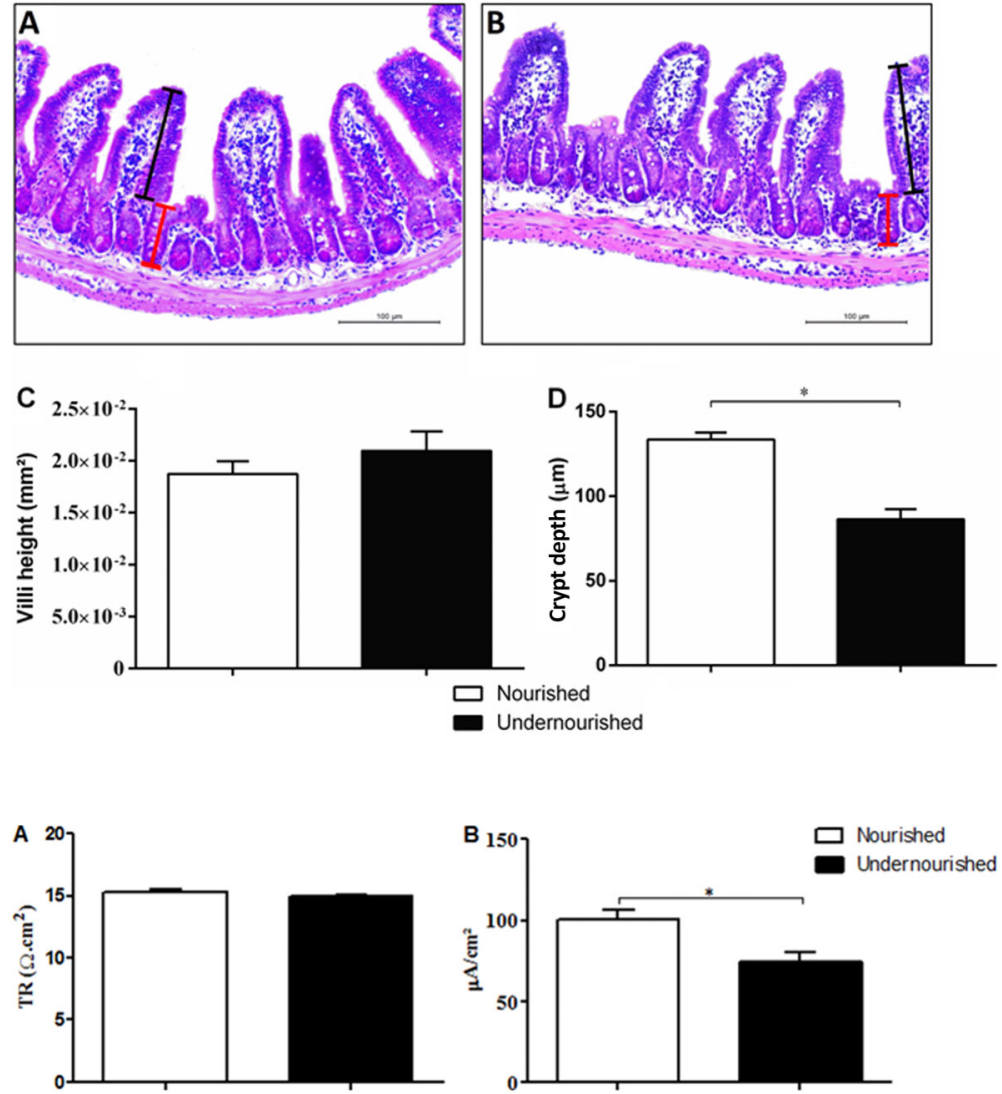

Figure 3. Photomicrographs and morphometric analysis of the ileum of nourished and undernourished mice. H\&E-stained sections from nourished $(A)$ and undernourished $(B)$ mice. Crypt depth and villi height are represented, respectively, by red and black lines in each group $(A, B)$. $C$, the index area of the villi and $D$, crypt depth from the ileum histological sections are shown for nourished and undernourished groups. Magnification $200 \times$. Data are reported as means $\pm S E(n=4)$. ${ }^{*} P<0.01$ (Mann-Whitney nonparametric test). undernourished group compared to nourished control $(133.6 \pm 4.12$ vs $86.50 \pm 5.871 \mu \mathrm{m} ; \mathrm{P}<0.001$; Figure 3D).

Impact of RBD diet for 7 days on basal short-circuit, electrogenic ion transport and tissue resistance

In order to investigate whether intestinal ionicsubstrate co-transport would be altered after 7 days of $\mathrm{RBD}$, we measured basal $\mathrm{I}_{\mathrm{sc}}$, electrogenic ion transports and transepithelial resistance of the ileum segment mounted in an Ussing chamber system. The basal $\mathrm{I}_{\mathrm{sc}}$ was reduced significantly in the undernourished group compared to the nourished group $(P=0.0297)$, while transepithelial resistance showed no difference (Figure 4).

We plotted the results in a concentration-effect curve analysis for glutamine, alanyl-glutamine and glucose substrates. The correspondent $\mathrm{pEC}_{50}$ values for each substrate did not differ between nourished and undernourished groups. Maximum responses were not statistically different between groups, except for the maximum glucose concentration $(P<0.05$; Figure 5$)$.

Effect of acute RDB on intestinal transporters and tight junctions transcription, and protein expression

The data showed different profiles of transcription of intestinal transports. mRNA transcriptions of SGLT-1 and
PEPT-1 were significantly higher in the undernourished group compared to the nourished group $(\mathrm{P}=0.0205$ and $\mathrm{P}=0.0037$, respectively). Conversely, $\mathrm{SN}-2$ transcription was significantly decreased in the animals who received RBD diet $(P=0.0091)$. No changes were found in relative transcriptions of CAT-1 and CFTR. Regarding the effect of RBD diet on mRNA concentration of tight junctions, claudin-2 and occludin transcription, were significantly increased in the undernourished group $(P=0.0003$ and $P=0.0427$, respectively; Figure 6). According to the mRNA results, we chose to evaluate the expression of proteins SGLT-1, PEPT, claudin-2 and occludin by western blotting. Unlike differences seen by mRNA analyses, no statistical difference was observed between undernourished and nourished groups for these proteins (Figure 7).

\section{Discussion}

In the present study, we demonstrated in a mouse model that the RBD (regional basic diet, from Northeastern Brazil) promotes undernutrition during a short period of consumption (7 consecutive days), with the objective to understand the early intestinal pathophysiology of undernourished children in developing countries $(24,25)$. In this model, moderate acute undernutrition is characterized by 
A

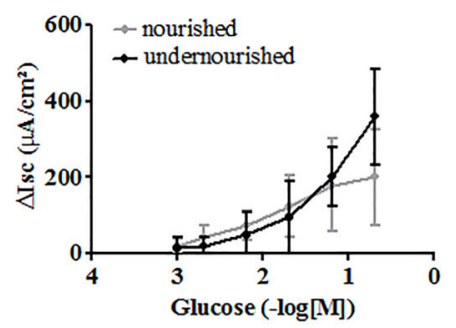

Nourished:

$\mathrm{pEC}_{50}=1.848 \mathrm{EC}_{50}=14.18 \mathrm{mM}$

$\mathrm{R} \max =200.6 \mu \mathrm{A} / \mathrm{cm}^{2} \mathrm{n}=6$

Undemourished:

$\mathrm{pEC}_{50}=1.302 \mathrm{EC}_{50}=49.86 \mathrm{mM}$ $\mathrm{Rmax}=359.8 \mu \mathrm{A} / \mathrm{cm}^{2} \mathrm{n}=9$

B

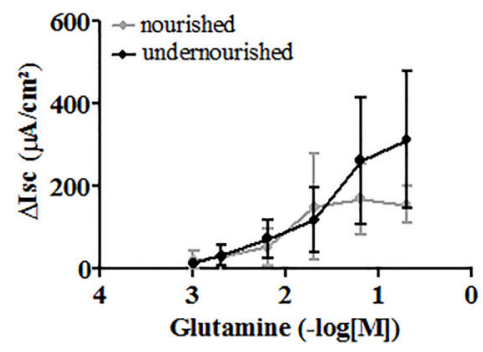

Nourished:

$\mathrm{pEC}_{50}=1.971 \quad \mathrm{EC}_{50}=10.69 \mathrm{mM}$

$\mathrm{Rmax}=156.0 \mu \mathrm{A} / \mathrm{cm}^{2} \mathrm{n}=6$

Undernourished: $\mathrm{pEC}_{50}=1.588 \quad \mathrm{EC}_{50}=25.82 \mathrm{mM}$ $R \max =313.6 \mu \mathrm{A} / \mathrm{cm}^{2} \mathrm{n}=11$

C

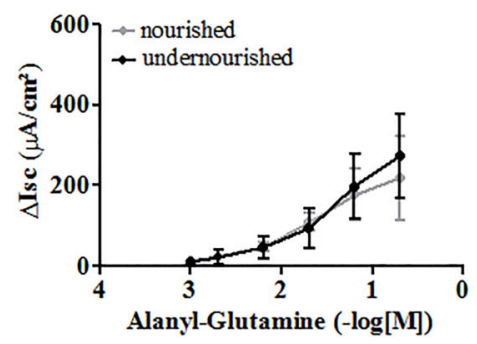

Nourished:

$\mathrm{pEC}_{50}=1.648 \mathrm{EC}_{50}=22.47 \mathrm{mM}$

$\mathrm{Rmax}=218.1 \mu \mathrm{A} / \mathrm{cm}^{2} \mathrm{n}=5$

Undernourished.

$\mathrm{pEC}_{50}=1.483 \mathrm{EC}_{50}=32.91 \mathrm{mM}$

$R \max =273.8 \mu \mathrm{A} / \mathrm{cm}^{2} \mathrm{n}=6$

Figure 5. Short-circuit current $\left(I_{\mathrm{sc}}\right)$ measured after cumulative addition of glucose $(A)$, glutamine $(B)$, and alanyl-glutamine $(C)$. Substrates were added at increasing concentrations $(1,2,7,20$, 70 , and $200 \mathrm{mM}$ ) at $30 \mathrm{~min}$ time intervals with subsequent measurement of $I_{s c}$. Results are reported as means $\pm S E(n=5-$ 11 Ussing chambers from four mice). $\mathrm{P}<0.05$, maximum responses were significantly different between groups only for the maximum glucose concentration (two-way ANOVA followed by the Bonferroni post hoc test).

impaired growth, decreased crypt depth with no alterations in villus area, reduced basal $\mathrm{I}_{\mathrm{sc}}$ and disturbance of gene transcription in intestinal components of the nutrient transport systems in the ileum, with no accompanying changes in protein expression.

Previously, RBD-induced undernutrition has been evaluated only under conditions of chronic exposure, $(11,12,26)$ with incomplete results about the short-term effects of RBD (i.e., no data about the electrophysiological parameters of absorption and their associated mechanisms). In addition, these studies did not evaluate the ileum portion of the small intestine.

RBD-induced undernutrition is characterized mainly by retardation of body weight gain $(11,27)$. Our results demonstrated this decline within the early days of consumption, which continued throughout daily monitoring. This effect might be attributed to the low nutritional value of this diet (protein-, fat-, and mineral-deficient) and hypophagia during the first 2 days of administration, with subsequent growth catch-up. Another study of RBD diet-induced undernutrition observed similar body weight reduction and food ingestion results (12). A multideficient diet with $7.44 \%$ protein vs a control diet with $20 \%$ protein caused malnutrition, reflected by poor growth and development as seen in other mouse models $(10,28)$.

Some studies have shown significant changes in the morphological architecture of microvilli and in the area of intestinal absorption during moderate to long periods of RBD feeding $(11,12)$. Our model of moderate acute undernutrition did not reveal significant differences in the area of the villi, but there was a decrease in the crypt depth. Another study indicated that RBD-induced malnutrition was characterized by decreased crypt depth (12). $A$ recent study of female adult mice fed with a diet similar to RBD also showed no alterations in villus height (13). Cell proliferation and apoptosis are indicated as potential underlying mechanisms for alteration of intestinal morphology by RBD exposure (12). Morphological and functional changes may reflect either beneficial or detrimental effects on nutrient and ion transports as an adaptive mechanism to poor nutrition (29). In a piglet model of shortterm protein-energy malnutrition, body weight decreased with no effects on villus height, intestinal permeability or occludin tight junction protein expression (30). Corroborating those findings, these data indicated that short-term undernourished states might lead to slightly altered cell proliferation and apoptosis, without drastic consequences on intestinal morphology or transport.

The small intestine maintains a complex system of transporters with electrophysiological properties necessary to maintain homeostasis associated with paracellular and transcellular fluxes via intestinal epithelial cells $(19,31,32)$. In this study, moderate acute undernutrition was characterized by a reduction in $\mathrm{I}_{\mathrm{sc}}$ at baseline. Previous studies have shown that the RBD and proteinrestricted diets can increase $I_{s c}$ in the jejunum of mice $(12,29)$. Confirming unaltered transporter expression, challenges with glucose, glutamine and alanyl-glutamine substrates showed similar $\mathrm{pEC}_{50}$ values between groups. Although the maximum response induced by glucose was different between undernourished and nourished groups, the $\mathrm{pEC}_{50}$ is the best measure of receptor/agonist affinity and its potency $(33,34)$. These data suggest a complete 

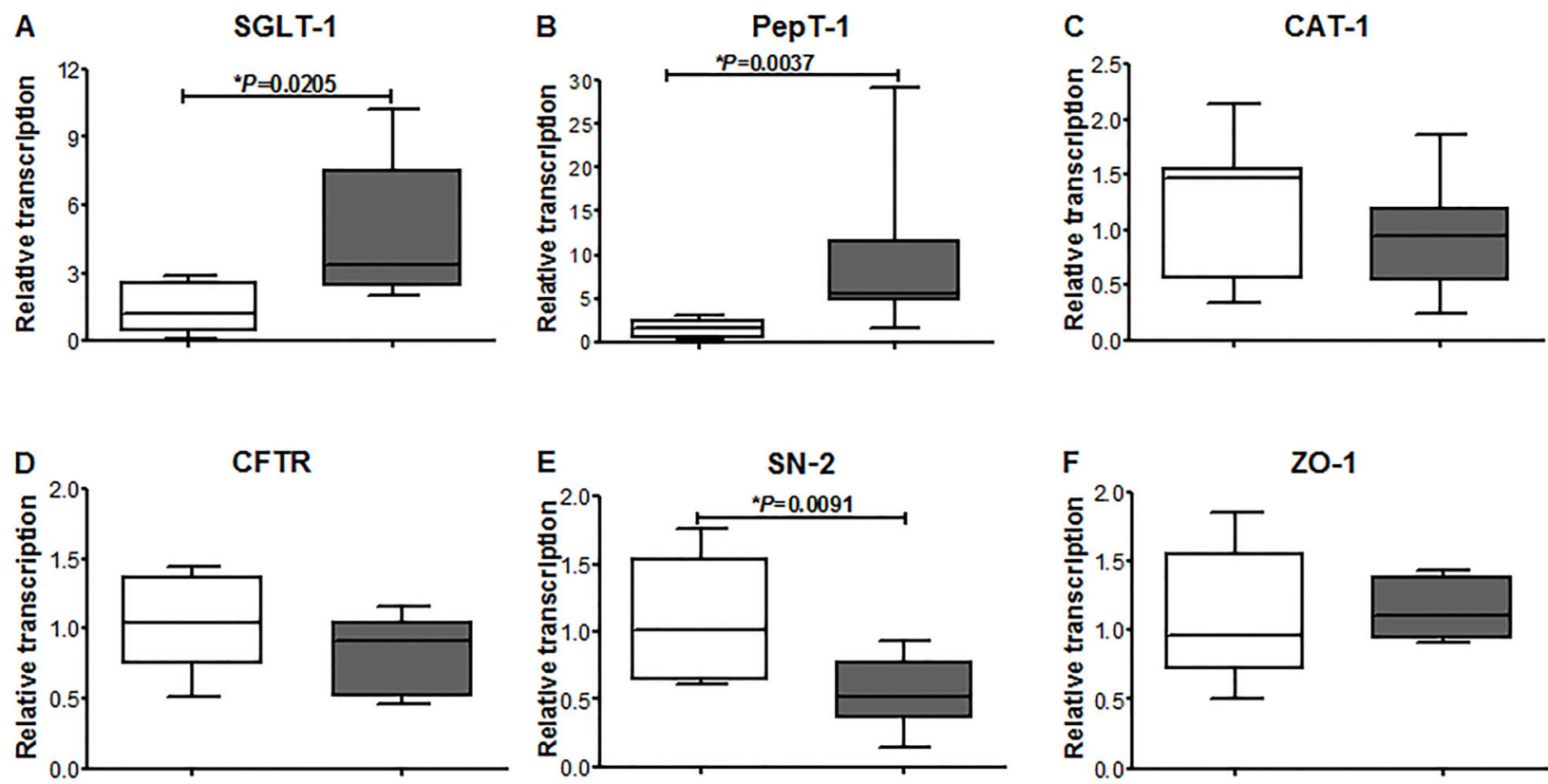

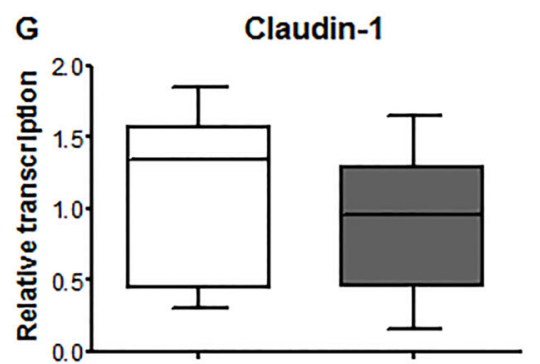

Nourished Undernourished
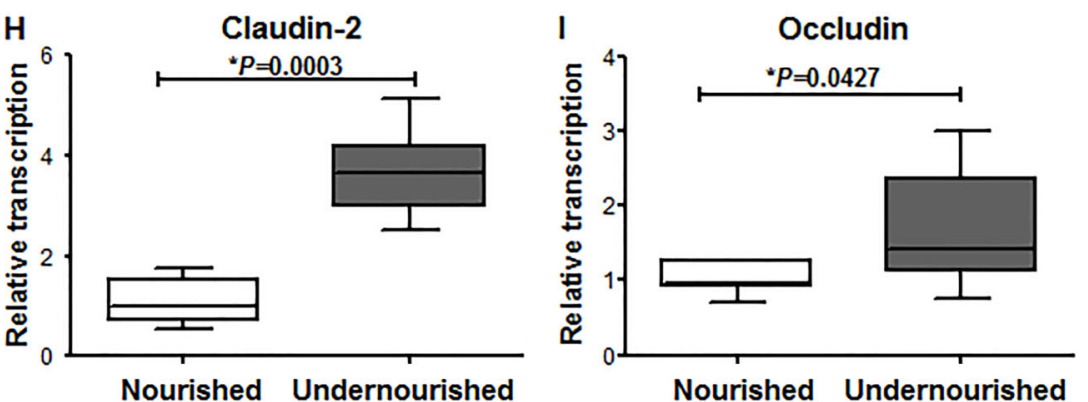

Figure 6. Effects of the regional basic diet on relative expression of $A$, SGLT-1; $B$, PepT-1; C, CAT-1; $D$, CFTR; $E$, SN-2; F, ZO-1; $G$, claudin-1; $H$, claudin-2; $I$, occludin. * $P<0.05$, Mann-Whitney test $(n=7)$.

responsiveness of the intestinal absorption ability of the undernourished ileum. Furthermore, transepithelial resistance was not altered, which corroborates the unimpaired paracellular transport (29).

In order to maintain membrane stability between epithelial cells in the small intestine, claudins play an important role in the complex intestinal transporters system, contributing for the proper functioning of SGLT-1 and PepT-1 carriers plus several transporters for amino acids $(19,35,36)$. In our study, undernutrition caused diverse regulation on mRNA levels of intestinal transporters and tight junctions: claudin-2, occludin, SGLT-1 and PepT-1 mRNAs were increased while SN-2 mRNA was decreased. Despite the variation on mRNA levels, the protein expression of SGLT-1, PetT-1, claudin-2 and occludin did not vary. The lack of correlation between mRNA and protein levels of intestinal transporters and tight junctions has also been reported in other studies that addressed dietary restrictions in animals
$(37,14)$. Furthermore, this study evaluated these parameters in parallel, and it is well known that mRNA and protein production rates of a gene may occur at different time-points $(38,39)$. Moreover, post-transcriptional and translational mechanisms of regulation might help to explain these findings (40). Furthermore, the protein expression results are in agreement with the results of $\mathrm{I}_{\mathrm{sc}}$-evoked substrates variation, measured in the concentration-effect approach.

It was shown previously that dietary protein restriction in pregnant rats promoted increased transcription and protein expression of intestinal transporter genes (SGLT-1 and PepT-1) in the duodenum of their offspring, but not in the jejunum or ileum (14). Interestingly, removal of luminal nutrition in rats, by applying total parenteral nutrition for induction of intestinal damage, also increased mRNA of some transporter genes, as PEPT-1, although it did not modify CAT1 and SN-2 (15). In addition, a study of 
A

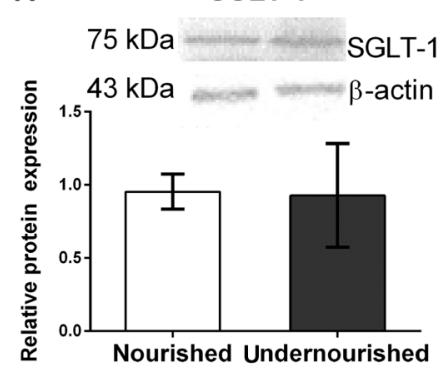

C

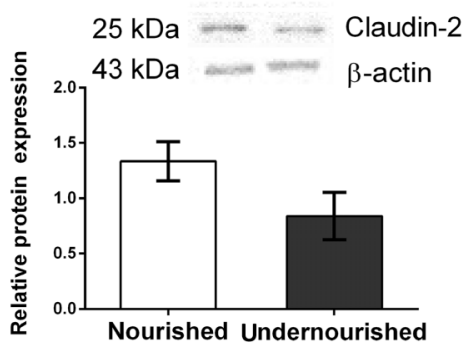

B

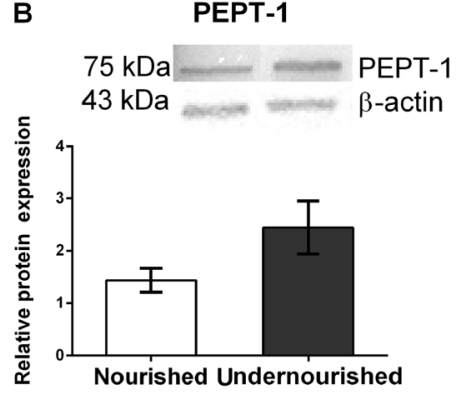

D

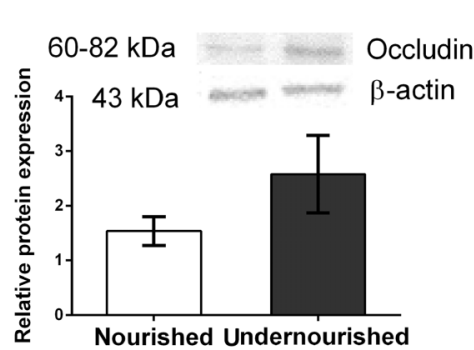

Figure 7. Effect of regional basic diet on protein expression of intestinal transporters and tight junctions. $A$, SGLT-1; $B$, PepT-1; $C$, claudin-2; $D$, occludin. Data are reported as means $\pm \mathrm{SE}(\mathrm{n}=4)$. $\mathrm{P}>0.05$, Mann-Whitney test. maternal undernutrition showed that newborn and weaning piglets did not have altered expression of mRNA for SGLT1 and PEPT-1 (16). Another study reported that in malnourished conditions the localization of SGLT1 does not change (19). In our RBD mouse model, transcriptional levels of SGLT-1 and PEPT-1 transporters were increased in the ileum, with no effects on protein expression. These data highlight the complex regulation of genetic expression of these transporters system (29).

This study has some limitations and perspectives. Biochemical tests, such as oral glucose tolerance test and lipid profile, could have been performed for evaluation of intestinal absorption to reinforce the non-alterations found. Moreover, measuring other physical parameters and behavioral characteristics could provide a more detailed evaluation of animal development. It is also important to point out that, although we were interested in early effects of RBD on intestinal transport, a gap of potential persistent effects of this diet in our model is still evident. Characterizing how the transition from moderate acute undernutrition to severe undernutrition occurs is a question for future studies.

\section{References}

1. ACF International. Taking action: nutrition for survival, growth and development. White paper. WHO; May 2010; www.who.int/pmnch/topics/child/acf_whitepaper.pdf.

2. Black RE, Allen LH, Bhutta ZA, Caulfield LE, de Onis M, Ezzati M, et al. Maternal and child undernutrition: global and regional exposures and health consequences. Lancet 2008; 371: 243-260, doi: 10.1016/S0140-6736(07)61690-0.
In conclusion, these results demonstrate the early effects of RBD on mice, indicating a state characterized by acute reductions in body weight and ileal crypt depth, without dramatic alterations to villus morphometry, intestinal nutrient transport, transepithelial resistance, and tight junction protein expression. By elucidating the early effects of undernutrition on physiology and in the gut, this study adds important value to the subject by indicating complex adaptive mechanisms of intestinal nutrient transporters and tight junction protein expression along the continuum from acute to chronic states of undernutrition.

\section{Acknowledgments}

This study was supported by National Council for Scientific and Technological Development (CNPq; \#573928/ 2008-8); Science Without Borders Special Visiting Researcher from CNPq to A.A.M. Lima and S.R. Moore, and a Fogarty International Center/National Institutes of Health Independent Scientist in Global Health Award (\#K02TW008767) to S.R. Moore
3. Black RE, Victora CG, Walker SP, Bhutta ZA, Christian P, de Onis $M$, et al. Maternal and child undernutrition and overweight in low-income and middle-income countries. Lancet 2013; 382: 427-451, doi: 10.1016/S0140-6736(13) 60937-X.

4. Adair LS, Fall $\mathrm{CH}$, Osmond $\mathrm{C}$, Stein $\mathrm{AD}$, Martorell $\mathrm{R}$, Ramirez-Zea M, et al. Associations of linear growth and 
relative weight gain during early life with adult health and human capital in countries of low and middle income: findings from five birth cohort studies. Lancet 2013; 382: 525-534, doi: 10.1016/S0140-6736(13)60103-8.

5. Horton S, Steckel RH. Malnutrition - Global economic losses attributable to malnutrition $1900-2000$ and projections to 2050. Copenhagen Consensus on Human Challenges. Copenhagen; 2011; http://www.copenhagenconsensus.com/sites/ default/files/malnutrition.pdf.

6. Rytter MJ, Kolte L, Briend A, Friis H, Christensen VB. The immune system in children with malnutrition - a systematic review. PLoS One 2014; 9: e105017, doi: 10.1371/journal. pone.0105017.

7. Caulfield LE, de Onis M, Blossner M, Black RE. Undernutrition as an underlying cause of child deaths associated with diarrhea, pneumonia, malaria, and measles. Am J Clin Nutr 2004; 80: 193-198.

8. Brigide P, Ataide TR, Baptista AS, Canniatti-Brazaca SG, Abdalla AL, Nascimento Filho $V$, et al. Bioavailability of iron in the regional basic diet (RBD) with dietary supplement in Brazil. Biol Trace Elem Res 2011; 140: 53-65, doi: 10.1007/ s12011-010-8681-6.

9. Teodosio NR, Lago ES, Romani SA, Guedes RC. A regional basic diet from northeast Brazil as a dietary model of experimental malnutrition. Arch Latinoam Nutr 1990; 40: 533-547.

10. Bolick DT, Roche JK, Hontecillas R, Bassaganya-Riera J, Nataro JP, Guerrant RL. Enteroaggregative Escherichia coli strain in a novel weaned mouse model: exacerbation by malnutrition, biofilm as a virulence factor and treatment by nitazoxanide. J Med Microbiol 2013; 62: 896-905, doi: 10.1099/jmm.0.046300-0.

11. de Queiroz CA, Fonseca SG, Frota PB, Figueiredo IL, Aragao KS, Magalhaes CE, et al. Zinc treatment ameliorates diarrhea and intestinal inflammation in undernourished rats. BMC Gastroenterol 2014; 14: 136, doi: 10.1186/1471-230X14-136.

12. Ueno PM, Oria RB, Maier EA, Guedes M, de Azevedo OG, Wu D, et al. Alanyl-glutamine promotes intestinal epithelial cell homeostasis in vitro and in a murine model of weanling undernutrition. Am J Physiol Gastrointest Liver Physiol 2011; 301: G612-G622, doi: 10.1152/ajpgi.00531.2010.

13. Brown EM, Wlodarska M, Willing BP, Vonaesch P, Han J, Reynolds LA, et al. Diet and specific microbial exposure trigger features of environmental enteropathy in a novel murine model. Nat Commun 2015; 6: 7806, doi: 10.1038/ ncomms8806.

14. Pinheiro DF, Pinheiro PF, Buratini J, Jr., Castilho AC, Lima $\mathrm{PF}$, Trinca LA, et al. Maternal protein restriction during pregnancy affects gene expression and immunolocalization of intestinal nutrient transporters in rats. Clin Sci 2013; 125: 281-289, doi: 10.1042/CS20120400.

15. Howard A, Goodlad RA, Walters JR, Ford D, Hirst BH. Increased expression of specific intestinal amino acid and peptide transporter mRNA in rats fed by TPN is reversed by GLP-2. J Nutr 2004; 134: 2957-2964.

16. Cao M, Che L, Wang J, Yang M, Su G, Fang Z, et al. Effects of maternal over- and undernutrition on intestinal morphology, enzyme activity, and gene expression of nutrient transporters in newborn and weaned pigs. Nutrition 2014; 30: 1442-1447, doi: 10.1016/j.nut.2014.04.016.
17. Furuse $M$, Hirase $T$, Itoh $M$, Nagafuchi $A$, Yonemura $S$, Tsukita S, et al. Occludin: a novel integral membrane protein localizing at tight junctions. J Cell Biol 1993; 123: 1777-1788, doi: 10.1083/jcb.123.6.1777.

18. Itoh $M$, Nagafuchi $A$, Yonemura $S$, Kitani-Yasuda $T$, Tsukita S, Tsukita S. The $220-k D$ protein colocalizing with cadherins in non-epithelial cells is identical to ZO-1, a tight junction-associated protein in epithelial cells: cDNA cloning and immunoelectron microscopy. J Cell Biol 1993; 121: 491-502, doi: 10.1083/jcb.121.3.491.

19. Wada M, Tamura A, Takahashi N, Tsukita S. Loss of claudins 2 and 15 from mice causes defects in paracellular $\mathrm{Na}+$ flow and nutrient transport in gut and leads to death from malnutrition. Gastroenterol 2013; 144: 369-380, doi: 10.1053/j.gastro.2012.10.035.

20. Field M. Intestinal secretion: effect of cyclic AMP and its role in cholera. $N$ Engl $J$ Med 1971; 284: 1137-1144, doi: 10.1056/NEJM197105202842008.

21. Coutinho BP, Oria RB, Vieira CM, Sevilleja JE, Warren CA, Maciel JG, et al. Cryptosporidium infection causes undernutrition and, conversely, weanling undernutrition intensifies infection. J Parasitol 2008; 94: 1225-1232, doi: 10.1645/ GE-1411.1.

22. Sirakov M, Borra M, Cambuli FM, Plateroti M. Defining suitable reference genes for RT-qPCR analysis on intestinal epithelial cells. Mol Biotechnol 2013; 54: 930-938, doi: 10.1007/s12033-012-9643-3.

23. Livak KJ, Schmittgen TD. Analysis of relative gene expression data using real-time quantitative PCR and the 2(-Delta Delta C(T)) Method. Methods 2001; 25: 402-408, doi: 10.1006/ meth.2001.1262.

24. Lima AA, Anstead GM, Zhang Q, Figueiredo IL, Soares AM, Mota RM, et al. Effects of glutamine alone or in combination with zinc and vitamin A on growth, intestinal barrier function, stress and satiety-related hormones in Brazilian shantytown children. Clinics 2014; 69: 225-233, doi: 10.6061/clinics/ 2014(04)02.

25. Platts-Mills JA, Babji S, Bodhidatta L, Gratz J, Haque R, Havt $A$, et al. Pathogen-specific burdens of community diarrhoea in developing countries: a multisite birth cohort study (MAL-ED). Lancet Glob Health 2015; 3: e564-e575, doi: 10.1016/S2214-109X(15)00151-5.

26. Maier EA, Weage KJ, Guedes MM, Denson LA, McNeal $\mathrm{MM}$, Bernstein DI, et al. Protein-energy malnutrition alters IgA responses to rotavirus vaccination and infection but does not impair vaccine efficacy in mice. Vaccine 2014; 32 : 48-53, doi: 10.1016/j.vaccine.2013.10.072.

27. Barros KM, Manhaes-De-Castro R, Lopes-De-Souza S, Matos RJ, Deiro TC, Cabral-Filho JE, et al. A regional model (Northeastern Brazil) of induced mal-nutrition delays ontogeny of reflexes and locomotor activity in rats. Nutr Neurosci 2006; 9: 99-104, doi: 10.1080/10284150 600772148.

28. Azevedo OG, Bolick DT, Roche JK, Pinkerton RF, Lima AA, Vitek MP, et al. Apolipoprotein E plays a key role against cryptosporidial infection in transgenic undernourished mice. PLoS One 2014; 9: e89562, doi: 10.1371/ journal.pone.0089562.

29. Ferraris RP, Carey HV. Intestinal transport during fasting and malnutrition. Annu Rev Nutr 2000; 20: 195-219, doi: 10.1146/annurev.nutr.20.1.195. 
30. Jacobi SK, Moeser AJ, Blikslager AT, Rhoads JM, Corl BA, Harrell RJ, et al. Acute effects of rotavirus and malnutrition on intestinal barrier function in neonatal piglets. World $J$ Gastroenterol 2013; 19: 5094-5102, doi: 10.3748/wjg.v19. i31.5094.

31. Gawenis LR, Hut H, Bot AG, Shull GE, de Jonge HR, Stien $X$, et al. Electroneutral sodium absorption and electrogenic anion secretion across murine small intestine are regulated in parallel. Am J Physiol Gastrointest Liver Physiol 2004; 287: G1140-G1149, doi: 10.1152/ajpgi.00177.2004.

32. Chen $M$, Singh $A$, Xiao $F$, Dringenberg $U$, Wang J, Engelhardt R, et al. Gene ablation for PEPT1 in mice abolishes the effects of dipeptides on small intestinal fluid absorption, short-circuit current, and intracellular $\mathrm{pH}$. $A m \mathrm{~J}$ Physiol Gastrointest Liver Physiol 2010; 299: G265-G274, doi: 10.1152/ajpgi.00055.2010.

33. Neubig RR, Spedding $M$, Kenakin $T$, Christopoulos A. International Union of Pharmacology Committee on Receptor Nomenclature and Drug Classification. XXXVIII. Update on terms and symbols in quantitative pharmacology. Pharmacol Rev 2003; 55: 597-606, doi: 10.1124/pr.55.4.4.

34. Fincan GSÖ, Gündüz MG, Vural ÝM, Simsek R, Sarioglu $Y$, Safak C. Investigation of myorelaxant activity of 9-aryl3,4,6,7-tetrahydroacridine-1,8-(2H,5H,9H,10H)-diones in isolated rabbit gastric fundus. Med Chem Res 2012; 21: 1817-1824, doi: 10.1007/s00044-011-9698-x.
35. Suzuki H, Tani K, Tamura A, Tsukita S, Fujiyoshi Y. Model for the architecture of claudin-based paracellular ion channels through tight junctions. J Mol Biol 2015; 427: 291-297, doi: 10.1016/j.jmb.2014.10.020.

36. Tamura A, Hayashi H, Imasato M, Yamazaki Y, Hagiwara A, Wada $M$, et al. Loss of claudin-15, but not claudin-2, causes $\mathrm{Na}+$ deficiency and glucose malabsorption in mouse small intestine. Gastroentero/ 2011; 140: 913-923, doi: 10.1053/ j.gastro.2010.08.006.

37. Elfers K, Marr I, Wilkens MR, Breves G, Langeheine M, Brehm R, et al. Expression of tight junction proteins and cadherin 17 in the Small intestine of young goats offered a reduced N and/or Ca diet. PLoS One 2016; 11: e0154311, doi: 10.1371/journal.pone.0154311.

38. Fournier ML, Paulson A, Pavelka N, Mosley AL, Gaudenz K, Bradford WD, et al. Delayed correlation of mRNA and protein expression in rapamycin-treated cells and a role for Ggc1 in cellular sensitivity to rapamycin. Mol Cell Proteomics 2010; 9: 271-284, doi: 10.1074/mcp.M900415MCP200.

39. Vogel C, Silva GM, Marcotte EM. Protein expression regulation under oxidative stress. Mol Cell Proteomics 2011; 10: M111, doi: 10.1074/mcp.M111.009217.

40. Vogel C, Marcotte EM. Insights into the regulation of protein abundance from proteomic and transcriptomic analyses. Nat Rev Genet 2012; 13: 227-232. 